\title{
Interpreting and Understanding: The Globalisation of Sport
}

\author{
Asst. Prof. Dr. Mathew Wallace \\ Girne American University \\ Sport Management Department \\ Cyprus
}

\begin{abstract}
Most people today accept that the world in which we live is changing at a rapid pace. Technological advancements, improved transport links and communication have made the world in which we live a "smaller place." Some argue that this process has enhanced and improved the overall quality of our everyday lives. Others argue that Globalisation is predominantly politically motivated imperialism. They say that it is driven by opportunists who are keen to spread Western culture, philosophy and ideology believing it to be superior and beneficial to all with sport being a tool used in the process. Sport is a core human activity that takes place in a rapidly changing world. Its mode of existence is continually diversifying to maintain is role in society. The essence of sport refers to the human desire to create, interact, naturally express and celebrate life. This paper provides the reader with perspective and a broader understanding of the globalisation of sport and its evolution and development.
\end{abstract}

Keywords: development, evolution, globalisation, society, sport, technological advancement

\section{Introduction}

Physical activity in itself is the ultimate expression of freedom in that it does not incur a single cost and proven to induce feelings of well-being both physically and psychologically (Biddle, et al. 2001). People throughout history have played with the basic idea of movement and excitement to produce organised games. These games create winners and losers, generate an atmosphere of competition, build reputations and induce highs and lows of fun amongst participants. Biddle, et al. (2001) explain that physical activity can have positive effects on; anxiety, depression, mood, emotion, self-esteem, cognitive functioning and psychological dysfunction. Unlike commodities that are bought and sold physical activity is free and available to all at any time.

Educational establishments recognise the importance of preserving, nurturing and emphasising the natural and fundamental meaning of sport (Mangan, 1981). They provide sporting activities that significantly contribute towards cultivating moral values, moral courage, loyalty, cooperation, the capacity to act fairly and to accept defeat (Morgan, 1997). They create powerful sets of principles and a coherent working ideology. They hold the view that sport is an activity to be cherished because of its natural affiliation with binding people together. Educational establishments instil into their pupils the value of playing by the rules and accepting outcomes in a respectful manner. They instil values that significantly help prevent pupils from lying, cheating and being unfair and encourage them to aim high and never to lose heart (Mangan, 1981). Educational establishments firmly believe that sport in schools raises the general spirit and develops important transferable social skills and values (Mangan, 1981). Nurturing the "pure play spirit" is evident not just in schools but also harboured amongst most amateur sports clubs in society. Also, localised sports pursued by friends of all ages at local leisure centres or on playing fields keep alive the pure play spirit of sport.

\section{Sport and Globalisation}

Elias and Dunning, (1986) explain that the last quarter of the $19^{\text {th }}$ century was characterised by the "sportisation" of sport. For example, the principal pastimes of cricket, horseracing and boxing began to emerge as modern sports. This was quickly followed by rugby, soccer, athletics and tennis. The sportisation of sport involved the fading of folk games and pastimes and the domination of rationalised achievement sports. This process lead to the development of international sports organisations and the growth of competitions between national teams (Elias and Dunning, 1986). Worldwide rules governing specific sport forms were accepted which firmly established global competition. The phenomena of Globalisation had an immense impact on civilizations across the globe in the 19th Century (Maguire, 2001). Houlihan (1994) explains that the theory of modernisation is built upon the notion that the world is experiencing the Westernisation of developing nations and that globalisation is a form of cultural imperialism. Modern sport has undergone a pattern of development from local to regional and then from national to international. Many sports had to modify and rearrange their original modes of existence to accommodate its influence. Some sports benefited, some were not affected and others were destroyed by the driving force of materialism. 
Better technology, improved transport and communication links between countries worked together towards changing the world in which we live and how we live our lives in it (Maguire, 2001). Competitors from all over the world are easily brought together to compete against each other in a wide variety of sports in the same Olympic city every four years (Espy, 2018). The globalisation of sport generates the need for world rankings for sports like golf and tennis. For example, every professional tournament in these sports contributes ranking points to players irrespective of which country the tournament is played in.

The development of professional sport improved the quality of performances given by the players involved (Elias and Dunning, 1986). The improved level of performance and increased structure to the competitions changed the public perception of it. Professional ethos and ethics created a sense that the true value of sport was to be found at professional level. Professional sport was significantly transformed by the largest sports organisations in the world (The IOC and FIFA) (Nauright and Pope, 2017). Organisations of this kind were largely responsible for the transformation of professional sport into a form of entertainment. Guttmann (2004) explains that "transformation" is the natural part of sports evolution whereby they are modified and rearranged, to be in line with the progress of commercialism. He says that it is an unavoidable part of the evolutionary process that has affected some sports negatively and some beneficially.

The Globalisation and modernisation of sport has meant that resources have become more readily available (Horne et al, 1999). International sport contributes towards developing relationships between countries. For example, travelling to other countries for competition involves travel, accommodation and evening entertainment. Conduct during the visits whist in the hotels helps build reputations of the countries involved. An important feature of international travel for players between countries will be the minor and seemingly insignificant simple daily communications and interactions. (e.g., the extent to which they were friendly, open and chatty or whether they were rude, obnoxious and noisy). Representing the country at national level whilst in competition abroad increases the importance of the interactions that take place because the relationships formed will leave lasting impressions. Competing in tournaments around the globe contributes towards breaking down barriers between countries enabling better relations to flow (Horne, et al 1999). Boosting tourism and intermingling in this way increases the friendliness that one country might have for another and helps create a truly cosmopolitan world.

Karl Marx predicted that future capitalist nations like Great Britain would exist according to strict, rigid and disciplined systems controlled by the Bourgeoisie. Houlihan (1994, pp. 1-25) says that within these systems sport has become a vehicle through which political objectives are met. He explains that sport has become a tool used for influencing access to the international arena, commercial gain and ideology, nation building and diplomacy. Nauright (2004) explains that sport has played a significant role within the globalisation process. In particular, he says that sport has contributed to the regeneration of some local, regional and national identities. Sports significance as a political tool has been recognised by politicians. For example, Espy (2018) comments that the requirement to send athletes abroad for competition can help towards establishing diplomatic relations. For example, the globalisation process of the PGA European Golf Tour has significantly extended the number of countries included in its scheduled tournaments. Examples include Australia, Africa, Asia and other countries outside Europe. Correspondingly cancelling a proposed sports visit to a nation can be used by a state to express discontentment towards a particular government and its policies.

For example, the English cricket team were advised not to compete in Zimbabwe by the English Prime Minister because of Robert Mugabe's political beliefs and his association with a dictatorship regime (Kamal and Campbell, 2002). These examples highlight the developing role that sport has in a global context. Kanin, (1981) argues that the Olympic Games were founded with political goals in mind. He explains that the games thrive on the ties they have global affairs. For example, the Olympics is dependant on commercial interests (e.g., the media, sponsors and the host city) and is controlled by the IOC. Hill's (2011) comment that "international sport needs the interest and support of politicians but not their interference" aptly summarises the concerns surrounding the welfare of sport in the political arena.

Professional sport has become a spectator sport capable of drawing in large crowds that generates huge sums of money making those involved with it rich. Murray (cited in Riordan, 1999) explains that FIFA has an influence in the sports world that can only be matched by the IOC. He notes that since its inauguration in 1904 its membership has grown to in excess of two hundred which is more than the member states of the United Nations. The work of large organisations like FIFA have ensured that football is now carefully packaged, marketed and franchised to suit a global audience via satellite channels. Nauright and Pope (2017) refer to twenty first century sport as the "sportsworld." They explain that it is having significant global impact and contains huge global markets with its commodification of sport and the competition to secure the right to host mega events. 
Nauright and Pope (2017) note that the "sportworld" contains the odour of corruption with the IOC and FIFA both being forced to undergo reforms. For example, Joseph Sepp Blatter had to end his long-standing career as FIFA president.

Maguire (2001) explains that the thrust of commercialism in sport relates to the intermingling of media, marketing, sponsors and sports organisations on a global scale. Maguire (2001) suggests that this kind of process has seen popular sport and culture become homogenised and associated with average ness and poor taste. He explains that sport has undergone a process of specularisation which is spearheaded by media. For example, media coverage of sport enhances the spectacle value and increases sports commodity value by manipulating modern technology producing slow motion shots, enhanced graphics and popular music. McChesney (cited in, Held and McGrew, 2003) argues that global media is dominated by transnational media companies that dominate US media (e.g., Sony, Disney, General Electric, Time Warner, News Corporation, Bertelsmann and Viacom \& Seagram). Media coverage of popular sport is carefully managed to make sure that its spectacle and commodity value is enhanced. Manchester United football club is a "finished" product of this process along with most sports in the $21^{\text {st }}$ century; it is compliant with the media demands placed on it. This club has become one of the most popular commodity signs recognised throughout the world and has become the symbol that represents materialistic achievement (Nauright, 2004). Transnational companies are part of a global culture and many have become economic giants (e.g., Nike). McChesney (cited in, Held and McGrew, 2003) explains that transnational companies can utilize methods of communication that include digital communication, satellite television and the internet to tackle national boundary issues.

Huntington (2014) explains that the process of globalisation is by nature associated with a sense of distant-less and of instant-ness. He argues that it transcends traditional ideas of national territory and directly challenges the traditional nation-state. Maguire (2001) adopts an interpretative approach to understanding the globalisation of sport. He analyses the level and type of cultural transfers that are transpiring in an attempt to establish whether cultural domination is occurring. He also assesses the potential for Non-Western cultures to influence Western patterns of consumption. Associated with this are questions concerning the authenticity of National identity and culture as well as the role indigenous sports play in the globalisation process. Maguire (2001) and other theorists suggest that there has been an increase in localised resistance to globalisation. They say that it is represented through the resurgence of traditional sports and cultures. Perhaps an example of a sport that is counteracting or challenging the effect of the homogenising process of globalisation (be it directly or indirectly) is falconry. Falconry in the Eastern part of the globe is conducted in a spirit that encapsulates the agony and pleasure of mans desire and fight for survival against the elements (Upton, 2002). The sheer beauty of falconry is created through its links to its mystical and sacred origins. The strength of its mode of existence lies in its ability to remain unflinchingly loyal to its origins without surrendering to the force of commercialism. Immense inflexibility has helped ensure that its basic principles are adhered to without being ravished by globalisation and modernisation. In the east, falconry continues to flourish in its natural form harbouring values relating to sincerity, simplicity, originality, and innocence (Upton, 2002). The game Ulac is a grotesque extreme sport involving polo with a freshly beheaded goat (Levine, 2003). This indigenous sport played in Asia may also represent a resistance to the overbearing, standardised, overly mass produced and homogenised global sport broadcast around the world. Resistance refers to how hegonomized members of society within the strict, rigid and disciplined systems controlled by the Bourgeoisie participate in cultural practises like sport to challenge their domination (Guilianotti, 2015). For example, physical activities like parkour and free running that have their own unique philosophies, values and cultures can be considered as countering and disputing the status quo and the professionalising, commercialising and modernisation processes of the globalisation of sport (Wallace and Apak, 2016).

\section{Conclusion}

The $20^{\text {th }}$ century witnessed the globalisation of sports and the diversification of sports cultures around the world. Maguire (2001) explains "global sport is a most powerful cultural transfer mechanism and carrier of deep culture and structure that carries a message of Western cosmology." Maguire (2001) comments that globalisation has made the contrasts between cultures diminish and varieties of cultural identities increase. This is largely due to the commingling of cultures, styles, images, commodities and consumer identities. Maguire (2001) explains that global flows are patterned by several competing processes that include; Africanisation, Americanisation (dominant), Europeanisation, Orientalisation and Hispanisation. He explains that this process is characterised by the multi dimensional integration of inter civilization encounters and various cultural flows.

Sport today plays a significant role in society on global scale. So much so that it has changed the emphasis of what cultural distinctions are important (Maguire, 2001). For example, postage stamps, military uniforms and national flags have become minor cultural distinctions in comparison to being associated with the World Trade Organisation, United Nations and United Peace Keeping, which has made national activities and attitudes more globally orientated. 
Nauright and Zipp, (2018) explain that what has been taking place, is the process of transforming traditional methods of sport into to modern day sports. For example, professional sport is driven by sophisticated ideas and ethos that draw attention to it from leaders and influential members of society. These people recognise sports power to generate strongly felt passions and emotions that create unity and a feeling of belonging (Anderson, 2006) (e.g., supporting or being part of a club or partaking in the sport itself).

The impact of globalisation and the move from traditional to modern sports has usually witnessed more rules, rigorous structures, increased demands on excitement levels in terms of impact of what is seen (Nauright and Zipp, 2018). Experts in the sports domain say that the world today has become a "sports global village" (Maguire, 2001). For example, major sporting events like the Football World Cup and the Olympic Games can be watched by the entire population of the world via various media networks (Nauright and Zipp, 2018). Massively improved transport facilities have meant that criss-crossing the globe to watch these historical spectacles has become a routine practise.

Globalisation has had both positive and negative affects on sport in society. Sport is a core human activity that has an integral role with economic, political and social evolution. It's essence, welfare, purpose and role must be fully understood and nurtured to help ensure that it remains to be a positive force in contemporary society.

\section{Bibliography}

Anderson, B. (2006) Imagined Communities: Reflections on the Origins and Spread of Nationalism (Rev. Ed.): London: Verso.

Biddle, S. Fox, K. Boutcher, S (2001) Physical Activity and Psychological Wellbeing. London: Routledge.

Elias, N. and Dunning, E. (1986) Quest for Excitement: Sport and Leisure in the Civilizing Process. Oxford: Blackwell.

Espy, R. (2018) The Politics of the Olympic Games (Rep. Ed.): Berkeley: University of California Press.

Guilianotti, R. (2015) Sport. A Critical Sociology (2 ${ }^{\text {nd }} E d$.): Cambridge: Polity.

Guttmann, A. (2004) From Ritual to Record. The Nature of Modern Sports. (U/D Ed.) New York: Columbia University Press.

Held and McGrew (2003) The Global Transformations Reader: Cambridge: Polity Press.

Hill, C. (2011) Olympic Politics: Athens to Atlanta 1896-1996. Manchester: Manchester University Press.

Houlihan, B. (1994) Sport and International Politics. Hemelhempstead: Harvester Wheat Sheaf.

Huntington, S. (2014) The Clash of Civilisations and the making of the New World Order. London: Penguin.

Kamal, A. and Campbell, D. (2002) No. 10 fury over England cricket trip to Zimbabwe: The Guardian, 29 Dec 2002. [Online] Available at: https://www.theguardian.com/uk/2002/dec/29/sport.politics [accessed 08/05/2019].

Kanin, D. (1981) A political History of the Olympic Games. Boulder. Col: Westview Press.

Levine, E. (2003) A Game of Polo with a Headless Goat: And Other Bizarre Sports Discovered Across Asia. London: Ardle Deutsch.

Maguire, J. (2001) Global Sport. Identities, Societies, Civilizations. Cambridge: Polity Press.

Mangan, J. A. (1981) Athleticism in the Victorian and Edwardian Public School. London: Falmer Press.

Morgan, W. J. (1997) Sport and the Making of National Identities A Moral View. Journal of the Philosophy of Sport, 14: 1, pp. 1-20.

Nauright, J. (2004) Global Games: culture, political economy, and sport in the globalized world of the twenty-first century. Third World Quarterly, 25:7, pp. 1325-36.

Nauright, J. Zipp, S (2018) The complex world of global sport, Sport in Society Cultures, Commerce, Media, Politics, 21:8, pp. 1113-1119.

Nauright, J. Pope. S. (2017) The twenty-first-century SportsWorld: global markets and global impact, Sport in Society. Commerce, Media, Politics, 20:12, pp. 1817-1820.

Riordan, J. (1999) The International Politics of Sport in the 20th Century. London: Routledge.

Upton, R. 2002. Arab falconry: history of a way of life. Surrey, BC Canada: Hancock House.

Wallace, M. and Apak, M. A Qualitative Exploration of Parkour and Free Running. International Journal of Basic \& Applied Sciences, 16: 06, pp. 12- 18. 